\title{
Preparation and characterization of activated carbon from nyamplung (Calophyllum inophyllum .L) seed shell waste: effect of activation temperature
}

\author{
Suritno Fayanto ${ }^{1}$, Sawaluddin ${ }^{2}$, Muhammad Anas ${ }^{3}$, Hunaidah ${ }^{4}$, Erniwati ${ }^{5}$, Vivi Hastuti ${ }^{6}$, \\ Rufa Mongkito $^{7}$ \\ \{Suritnofayanto@gmail.com ${ }^{1}$, sawaludinsiowan@gmail.com², anas.physedu.uho@gmail.com ${ }^{3}$ \}
}

Physics Education, Universitas Ahmad Dahlan, Jl. Pramuka No.42 Yogyakarta 55161 Indonesia ${ }^{1}$, Physics Education, Universitas Halu Oleo, Jl. H.E.A. Mokodompit, Kendari 93231 Indonesia $^{234567}$

\begin{abstract}
The aims of this research is preparation activated carbon from a waste of seed of nyamplung and to know the surface structure of activated carbon of seed shell and also carbon composition contained in nyamplung seed shell activated carbon. The samples were then sieved with a size of 100 mesh and then carbonated using pyrolysis at 200$400{ }^{\circ} \mathrm{C}$ for 7 hours, then activated 10 grams using a 30-minute steam pressure with a temperature range from $600{ }^{\circ} \mathrm{C}, 700{ }^{\circ} \mathrm{C}, 800^{\circ} \mathrm{C}$ and $900^{\circ} \mathrm{C}$. The sample was characterized using SEM, proximate and ultimate analysis methods. The result of analysis is obtained that at temperature $700{ }^{\circ} \mathrm{C}$ has a very large pore diameter of $46 \mathrm{~nm}$ while the result of proximate and ultimate characterization shows the highest carbon content obtained an activation temperature of $800{ }^{\circ} \mathrm{C}: 97,32 \%$. These results indicate that the pore structure is in the mesopori category.
\end{abstract}

Keywords: characterization, variation temprature activation, nyamplung.

\section{Introduction}

Indonesia is a country that there are many types of biofuel crops scattered throughout the archipelago. One type of biofuel plant is a nyamplung plant. Nyamplung is an annual tropical plant species of the mangosteen family (Guttifera) with the botanical name Calophyllum Inphyllum L[1]. Nyamplung plant has characteristics such as having a stone fruit, round shape with a diameter of 2-4 cm and brown [2], while nyamplung seed has the potential to produce alternative energy in the form of biofuel and other oil derivatives that are very beneficial to the economy [3]. On average each nyamplung tree has a high oil content of 55\% in fresh seeds and $70.5 \%$ in dry beans [4].

Before being processed into biofuel energy seed nyamplung first separated between seeds and shell so it can produce oil called oil nyamplung. The productivity of nyamplung seeds is very high and varies between $40-150 \mathrm{~kg} / \mathrm{tree} /$ year or about 20 tons/ha/year and higher than other types of plants such palm (6 tons/ha/year) [5]. One of the raw materials that can be developed as activated carbon is nyamplung seed shell (Calophyllum inophyllum Linn) which is waste from processing of oil of nyamplung and not yet exploited.

The yield of nyamplung oil produces nyamplung shell into the garbage. Trash of nyamplung seed shell is often considered useless and only becomes garbage that has many

ICCSET 2018, October 25-26, Kudus, Indonesia

Copyright (C) 2018 EAI

DOI 10.4108/eai.24-10-2018.2280629 
benefits. One utilization can be used as activated carbon/briquette. Seed shell or shell can be utilized to be Carbon briquettes using furnace \& condensation tool. Smoke that comes out of the carbonization process is accommodated into liquid smoke that can be used as a preservative, liquid fertilizer, and environmentally friendly pesticides [5]. To maximize its function as activated carbon several things to note include the order of pores and composition of carbon. The arrangement of the pores greatly affects the quality of the activated carbon due to the pores contained in the activated carbons have the most important benefits in the adsorption process. Some researchers have done Santiyo proposed the characterization of surface structure of activated carbon of nyamplung seed shell by using chemical activation method with concentration of $\mathrm{H}_{3} \mathrm{PO}_{4}(5 \%$ or $10 \%)$ solution at activation temperature $600{ }^{\circ} \mathrm{C}$ and $700{ }^{\circ} \mathrm{C}$ obtained that at 700 activation temperature with additional solution $5 \%$ and $10 \%$ concentrations showed an open pore shape with an average size of $5 \mu \mathrm{m}[6]$.

Given the importance to create and characterize the surface structure and composition contained in the activated carbon of seed shell nyamplung seed, the researchers are interested to conduct research on the making and characterization of activated carbon nyamplung seed shell by using variation activation temperature techniques.

\section{Materials and methods}

\subsection{Raw materials}

The sampling of nyamplung seed shell material in Siompu Subdistrict, Buton Selatan District, Southeast Sulawesi Province Indonesia. the seed shell nyampung then washed using distilled water and then dried for 5 hours by the sun.

\subsection{Preparations of activated carbon}

The carbonation process is carried out by pyrolysis which lasts about \pm 8 hours with the heating temperature of $\pm 200{ }^{\circ} \mathrm{C}-400{ }^{\circ} \mathrm{C}$ to produce charcoal. One sign that nyamplung seed shell has become charcoal if the smoke produced at the time of carbonization has begun to decrease or almost run out. After carbonization, the seeds of nyamplung seed husk was crushed by using mortar, then sieving with a size of 100 mesh until obtained by nyamplung seed charcoal powder. Furthermore, the activation process is done in an electric furnace with temperature variations starting from $600{ }^{\circ} \mathrm{C}, 700{ }^{\circ} \mathrm{C}, 800{ }^{\circ} \mathrm{C}$ and $900{ }^{\circ} \mathrm{C}$. Each sample has the same weight that is 10 grams for each activation temperature. After that activation is done by heating the charcoal powder in the electric furnace with activation time for 30 minutes.

\subsection{Characterization of activated carbon}

The Characterization of activated carbon by using Electron Scanning microscope and characterization using proximate and ultimate analysis techniques. Characterization using Scanning electron microscope to know the structure and size of the surface of activated carbon. For each analysis use, Scanning electron microscope using 2 gram activated carbon activation result. 
Proximate analysis is used to determine water content, determine the volatile matter, determine ash content and bound carbon content. The process of heating the cup at $105^{\circ} \mathrm{C}$ for 30 minutes, then cooled for 15 minutes then weighed to know the empty mass. Repeated until a constant mass is obtained, to obtain a mass difference between two weighing processes of not more than 2 grams, weighing a total of 5 grams of nyamplung shell charcoal sample, inserting a weighed sample into a bowl already known to the empty mass, sample into the oven, heating the sample at $105^{\circ} \mathrm{C}$ for 3 hours so that the whole water evaporates. The sample is then cooled by avoiding external temperature contamination, Considering the cup containing the sample that has been cooled in the estimator. Calculates levels of volatile matter determine ash content and bound carbon content.

The ultimate analysis is used to determine the wet weight (\%) and dry weight (\%).Wet weight is also known as water dried base (adb) whereas dry weight is known as the dried basis $(\mathrm{dB})$. The results obtained from the analysis of elements analyzed by the ultimate method of element presentation in adb (\%) are not yet real value, wherein Inherent Moisture (IM) in the sample is still analyzed. To get real value, adb must be converted to $\mathrm{db}$ in the following way:

Where;

$$
d b(\%)=a d b(\%) \frac{100-I M}{100}
$$

$$
\begin{aligned}
& d b(\%)=\text { dried basis } \\
& a d b(\%)=\text { air dried basis } \\
& I M \quad=\text { Inherent Moisture }
\end{aligned}
$$

\section{$3 \quad$ Results and discussion}

\subsection{Characterization of active carbon surface structure using scanning electron microscope (SEM)}

Characterization of pore surface structure was performed using Scanning Electron Microscope (SEM) with SEM 1000x magnification. This analysis aims to determine the surface topography of a material due to changes in activation temperature.

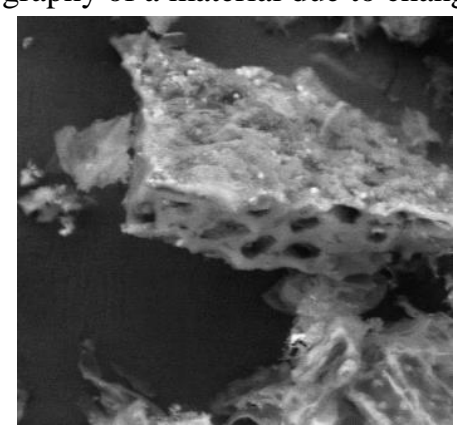

Fig. 1. Activation $600^{\circ} \mathrm{C}$.

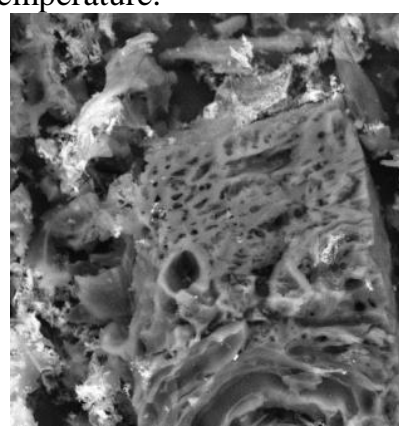

Fig. 2. Activation $700^{\circ} \mathrm{C}$. 


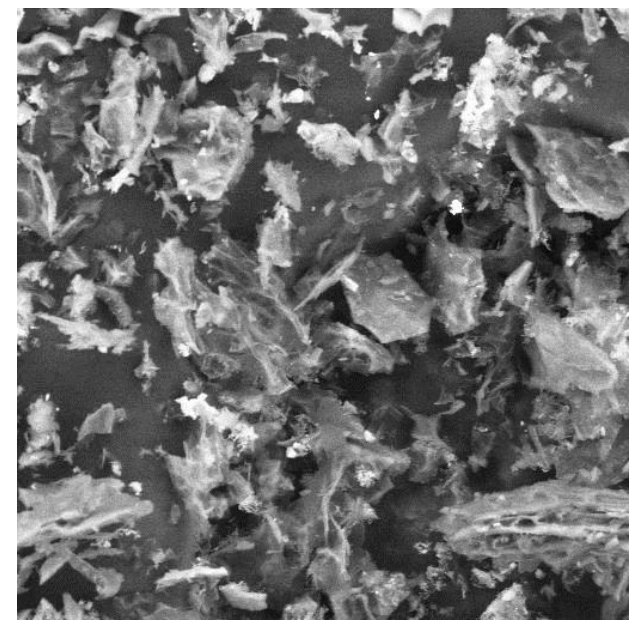

Fig. 3. Activation $800^{\circ} \mathrm{C}$.

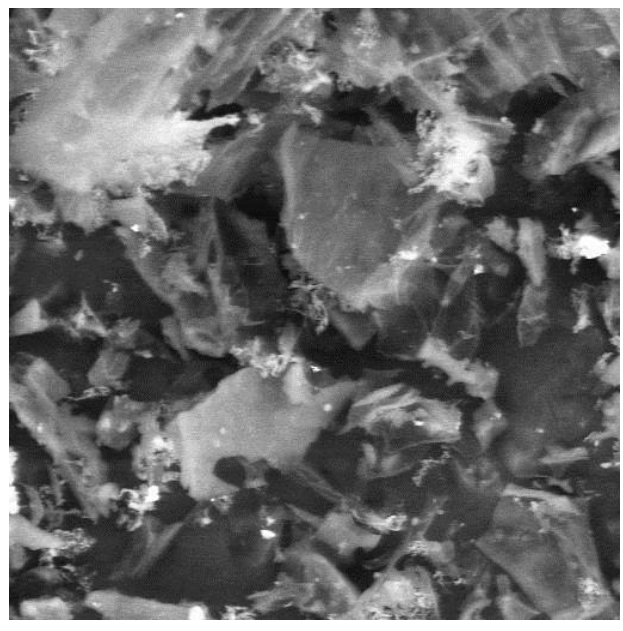

Fig. 4. Activation $900^{\circ} \mathrm{C}$.

To determine the magnitude of pore diameter SEM characterization in auxiliary by using Image-J analysis. The results showed an activation temperature of $600{ }^{\circ} \mathrm{C}, 700{ }^{\circ} \mathrm{C}, 800{ }^{\circ} \mathrm{C}$ and $900{ }^{\circ} \mathrm{C}$ the resulting pore diameter was in pore mezzo category with a diameter size of $26 \mathrm{~nm}$, $46 \mathrm{~nm}, 10 \mathrm{~nm}$ and $9 \mathrm{~nm}$ as illustrated by Table 1. Henk suggests that the size of the pore diameter is said to be a mezzo pore when between $2 \mathrm{~nm}-50 \mathrm{~nm}$ [7].

Table 1. Results of Image-J analysis on each activation temperature.

\begin{tabular}{ccc}
\hline Variation of activation temperature $\left({ }^{(} \mathrm{C}\right)$ & Total pore & Average size $(\mathrm{nm})$ \\
\hline 600 & 8835 & 26 \\
700 & 32464 & 46 \\
800 & 3416 & 10 \\
900 & 3374 & 9 \\
\hline
\end{tabular}

Tham argued that the formation of pores due to the evaporation of airborne substances from raw materials due to the carbonization process [8]. Carbonization has caused the components of degraded materials to produce gas products $\left(\mathrm{CO}, \mathrm{CO}_{2}\right.$, hydrogen, and methane), liquid products (tar, hydrocarbons, wood vinegar, water) and solid products. SEM and Image-J test results for temperatures of $600{ }^{\circ} \mathrm{C}$ and $700{ }^{\circ} \mathrm{C}$ have shown the presence of pores with total pores produced as shown in Table 1 . This is because there are some elements that are degraded and evaporated due to the increase in activation temperature which causes the formation of small cavities [9]. Next Jeujun suggests that during the activation process, the irregular activated carbon crystallite plates undergo a shift so that the crystallite surface becomes exposed to the activating gas which can drive the hydrocarbon residues [10]. This is most likely due to the higher activation temperature so the activated carbon produced 
decreased from substance more organic impurities and organic bonds are released and at an activation temperature of $800{ }^{\circ} \mathrm{C}$ and $900{ }^{\circ} \mathrm{C}$, there is evaporation of organic matter [11].

\subsection{Proximate analysis of activated carbon of nyamplung seed shell}

Proximate analysis was conducted to find out the amount or the level of water content, ash content, volatile substance and carbon content attached to activated charcoal of nyamplung seed shell. The data obtained from the analysis results by using proximate analysis method that is the concentration of water content, ash content, volatile substance and carbon content bound in the active charcoal of nyamplung seed shell in percent (\%). Activated charcoal data of nyamplung seed shell using proximate analysis method is shown in Table 2.

Table 2. Analysis of activated coconut shell of nyamplung seed to activation temperature variation with the proximate analysis method

\begin{tabular}{ccccc}
\hline \multirow{2}{*}{\begin{tabular}{c} 
Variation of activation $\begin{array}{c}\text { Quality of active carbon (\%) } \\
\text { temperature (C) }\end{array}$ \\
\cline { 2 - 5 }
\end{tabular}} & Water content & Ash content & $\begin{array}{c}\text { Levels of substances } \\
\text { evaporate }\end{array}$ & $\begin{array}{c}\text { The carbon content is } \\
\text { bound }\end{array}$ \\
\hline 600 & 0,30 & 1,42 & 2,65 & 95,63 \\
700 & 0,31 & 1,44 & 1,15 & 97,10 \\
800 & 0,31 & 1,27 & 1,10 & 97,32 \\
900 & 0,34 & 1,43 & 1,02 & 97,21 \\
\hline
\end{tabular}

Based on the results of the research proximate analysis Table 2 The lowest water content $(0.30 \%)$ is present in the shell of activated seed shell of temperature $600{ }^{\circ} \mathrm{C}$. This low water content indicates that the free water content and the bound water contained in the nyamplung seed shell charcoal have evaporated during the carbonization process. In contrast to high water content other than due to the hygroscopic nature of the activated charcoal, and also the presence of water vapor molecules trapped within the active hexagonal charcoal grille, especially in the cooling process and mass measurement. This then affects the instability of water content.

Ash content will affect the quality of activated charcoal as an adsorbent. Ash content is the amount of waste material from the end of the combustion process. The instability of ash content is caused by the oxidation process in activated carbon especially at high temperatures [12]. The statement is in line with the results obtained in Table 2 where the ash content obtained does not show a clear cycle as the activation temperature increases. Since the highest ash content was obtained an activation temperature of $700{ }^{\circ} \mathrm{C}(1.44 \%)$ and the lowest was obtained an activation temperature of $800{ }^{\circ} \mathrm{C}(1.27 \%)$. The levels of volatile substances depend on the carbonization process and the given temperature. If the process of long carbonization and increased temperature will further reduce the percentage of its evaporating substance [13]. The bound carbon content is the fraction of $\mathrm{C}$ in the char. The bound carbon content is influenced by water content, volatile substances, and ash content.In this research, the maximum carbon concentration was obtained at an activation temperature of $800{ }^{\circ} \mathrm{C}$ that is $97,32 \%$. 


\subsection{Ultimate analysis of activated carbon of nyamplung seed shell}

The ultimate analysis was conducted to determine the size or amount of carbon, hydrogen, nitrogen and sulfur content contained in the active charcoal of nyamplung seed shell. The data obtained from the analysis using the ultimate analysis method (Ultimate Analysis) is the concentration of the element content in the activated carbon of cashew nutshell in the percentage $(\%)$. The data on cashew seed cashew carbon by using the ultimate analysis method is shown in Table 3.

Table 3. Analysis of activated coconut shell of nyamplung seed to activation temperature variation ( $\mathrm{adb}$ conversion result into $\mathrm{db}$ ).

\begin{tabular}{ccccc}
\hline \multirow{2}{*}{$\begin{array}{c}\text { Variation of activation } \\
\text { temperature }\left({ }^{\circ} \mathrm{C}\right)\end{array}$} & Carbon & Hydrogen & Nitrogen & sulphur \\
\cline { 2 - 5 } & 78,21 & 3,32 & 0,19 & 0,05 \\
600 & 85,24 & 2,02 & 0,40 & 0,06 \\
\hline
\end{tabular}

For the carbon content (C) of the three samples analyzed, the activation temperature of $800{ }^{\circ} \mathrm{C}$ has the highest carbon content of $85.24 \%$ while for the activation of temperature $600{ }^{\circ} \mathrm{C}$ of $78.21 \%$ and without activation of $74.82 \%$. From these results, it is clear that the higher the activation temperature the carbon content obtained will be greater. This result shows that as high as the activation temperature, the hydrogen values contained in the sample will decrease. Iskandar revealed that the increasing temperature of carbonization and the longer the activation time oxygen and hydrogen content decreases because it has volatile properties at high heating [14]. While for the percentage of nitrogen $(\mathrm{N})$ content in this analysis did not show a clear cycle where nitrogen $(\mathrm{N})$ content was activated with a temperature of $600{ }^{\circ} \mathrm{C}$, the nitrogen content decreased to $0.19 \%$. But at the activation temperature of $800{ }^{\circ} \mathrm{C}$, the value of nitrogen content went up by $0.40 \%$. In the process of activation also formed new pores due to the erosion of carbon atoms through oxidation or heating [15].

The sulfur content (S) cycle increases with the activation temperature, where the lowest sulphur content is obtained in the non-activated treatment of $0.04 \%$ while for the activation of temperature $600{ }^{\circ} \mathrm{C}$ by $0.05 \%$ and the activation of the temperature of $800{ }^{\circ} \mathrm{C}$ by $0.06 \%$., of the four levels studied, sulfur content (S) is an element that has the smallest percentage. The results of this study indicate that the active charcoal of seed shell nyampung have better quality than the quality of activated charcoal from other materials.

\section{Conclusion}

From the characterization using scanning electron microscope, analysis of ultimate proximate and analysis can be concluded that the higher the activation temperature than the size of the resulting pore. Activated carbon nyamplung seed shell is in the mesopori category located at $2 \mathrm{~nm}-50 \mathrm{~nm}$. The result of the analysis of the carbon content produced is $97.32 \%$ and the ultimate analysis $85,24 \%$ at the activation temperature of $800{ }^{\circ} \mathrm{C}$. 


\section{Acknowledgements}

Our thanks the head of physics education department Halu Oleo University of the research grants given to us, the head of the basic development and physics laboratory and to the research developer. Thanks to Dr. Muh. Anas for the guidance during the research process.

\section{References}

[1] O. Friday, J, B. Dana, “Chalophyllum inophyllum (kamani),” Perm. Agric. Resour., pp. 1-17, 2006.

[2] A. E. Atabani and A. D. S. César, "Calophyllum inophyllum L. - A prospective non-edible biodiesel feedstock. Study of biodiesel production, properties, fatty acid composition, blending and engine performance,” Renew. Sustain. Energy Rev., vol. 37, pp. 644-655, 2014.

[3] W. K. Krishnakumar, N. Palanisamy, K. Maheshwar, H. Kannan, C, S, "Manual of economically important foresty species in south india," Inst. For. Genet. Tree Breed. Press, pp. 169-179, 2010.

[4] K. Christina, N. Edwin, S. Herman, H. Yohanes, "Pembuatan biodiesel dari minyak nyamplung dengan menggunakan katalis berbasis kalsium," J. Widya Tek., vol. 2, pp. 26-30, 2011.

[5] H. Budi, L. Eritrina, W. Tri, M, "Budidaya tanaman nyamplung (callophyllum inopyllum L) untuk bioenergi dan prospek pemanfaatan lainnya," IPB Press, pp. 20-40, 2014.

[6] P. Satiyo, W. Wasri, S. Gustan, "Karakterisasi permukaan arang aktif tempurung biji nyamplung," J. Makara Teknol., vol. 15, pp. 17-24, 2011.

[7] M. Henk, G, "Particle size measurements," Sci. Springer Press, pp. 34-36, 2009.

[8] L. Tham, Y, J. Shamala, D, A. Nur, H, A, L. Ahmad, M, A. Puziah, A, "Effect of activation temperature and heating duration on physical characteristics of activated carbon prepared from agriculture waste," Int. J. Thai Soc. High. Educ. Institutes Environ., vol. 3, pp. 143-148, 2010.

[9] M. N. Mohd Iqbaldin, I. Khudzir, M. I. Mohd Azlan, A. G. Zaidi, B. Surani, and Z. Zubri, "Properties of coconut shell activated carbon," J. Trop. For. Sci., vol. 25, no. 4, pp. 497-503, 2013.

[10] J. Katesa, S. Junpiromand, and C. Tangsathitkulchai, "Effect of Carbonization Temperature On Properties of Char And Activated Carbon From Coconut Shell," Suranaree J. Sci. Technol., vol. 20, no. 4, pp. 269-278, 2013.

[11] A. Legrouri, K. Harti, M, E. Ouman, M. Khouya, E. Wahbi, R. Hannache, H. Zarrouk, "Characterization and evaluation performance of activated carbon prepared from coconut shell argan," J. Chem. Pharm. Res., vol. 4, pp. 5081-5088, 2012.

[12] I. Thio, C, C. Magdalena, M, M. Jaka, S. Yohanes, S. Suryadi, "Activated carbon from durian shell: Preparation and characterization," J. Taiwan Inst. Chem. Eng., vol. 40, pp. 457-462, 2009.

[13] D. Kunbin, Y. Jinhui, P. Srinivasakannan, C. Libo, Z. Hongying, X. Xinhui, "Preparation of high surface area activated carbon from coconut shells using microwave heating," J. Bioresour. Technol. Elsevier, vol. 110, pp. 6163-6169, 2010.

[14] Iskandar, "Analisis Unsur Karbon Aktif Tempurung Kelapa Sawit dengan Metode Analisis Ultimat," ITB Press, pp. 6-40, 2012.

[15] R. Kadir, K. Awang, Z. Khamaruddin, and Z. Soit, "Chemical compositions and termiticidal activities of the heartwood from calophyllum inophyllum 1," An. Acad. Bras. Cienc., vol. 87, no. 2, pp. 743-751, 2015. 